\title{
Stability evaluation of tocopheryl acetate and ascorbyl tetraisopalmitate in isolation and incorporated in cosmetic formulations using thermal analysis
}

\author{
Mariana Mandelli de Almeida ${ }^{1, *}$, Cibele Rosana Ribeiro de Castro Lima ${ }^{1}$, Joyce Santos Quenca- \\ Guillen$^{1}$, Elder Moscardini Filho², Lucildes Pita Mercuri², Maria Inês Rocha Miritello Santoro ${ }^{1}$, \\ Erika Rosa Maria Kedor-Hackmann ${ }^{1}$
}

\author{
${ }^{1}$ Pharmacy Department, Faculty of Pharmaceutical Sciences, University of São Paulo, ${ }^{2}$ Department of Exact and Earth \\ Sciences, Faculty of Chemistry, Federal University of São Paulo
}

\begin{abstract}
In view of the increase in the number of cosmetic preparations containing antioxidant vitamins, chiefly, due to their action in preventing the process of skin aging, there is a need to develop pre-formulation studies and to validate analytical methods in order to obtain high quality products. Thus, the objective of this research was to evaluate and compare the thermal behavior of tocopheryl acetate and ascorbyl tetraisopalmitate as raw materials, and incorporated into a base cream. Thermogravimetry (TG / DTG) and differential scanning calorimetry (DSC) were used for this purpose. Both vitamins were found to be stable up to $250^{\circ} \mathrm{C}$. The base cream (placebo) and the sample (base cream containing the vitamins) presented different weight loss. Thermal analysis has shown itself to be an excellent tool for the characterization of these vitamins and can be used in routine analysis for quality control of this type of cosmetic formulation.
\end{abstract}

Uniterms: Thermal analysis. Cosmetic emulsion/qualitative analysis. Cosmetics/quality control. Tocopheryl acetate/antioxidant action. Ascorbyl tetraisopalmitate/antioxidant action. Vitamins/use in cosmetics.

\begin{abstract}
Considerando o potencial antioxidante das vitaminas utilizadas em produtos cosméticos, seu uso na prevenção do processo de envelhecimento da pele e a necessidade de estudos de pré-formulação que garantam o desenvolvimento de cosméticos de qualidade, foi objetivo deste trabalho avaliar e comparar o comportamento térmico dos ativos acetato de tocoferila e tetraisopalmitato de ascorbila, matériasprimas, isoladamente e incorporados em creme base. As técnicas termogravimetria/termogravimetria derivada (TG/DTG) e calorimetria exploratória diferencial (DSC) foram utilizadas para tal finalidade. Verificou-se que as vitaminas mantiveram-se estáveis até a temperatura de, aproximadamente, $250{ }^{\circ} \mathrm{C}$, observando-se diferença na perda de massa entre o creme base e o creme base associado às vitaminas. Assim sendo, a análise térmica mostrou-se como excelente ferramenta para caracterização das vitaminas e do creme base, podendo ser empregada em análises de rotina no controle de qualidade deste tipo de formulação cosmética.
\end{abstract}

Unitermos: Análise térmica. Emulsão cosmética/análise qualitativa. Cosméticos/controle de qualidade. Acetato de tocoferila/potencial antioxidante. Tetraisopalmitato de ascorbila/ potencial antioxidante. Vitaminas/uso em cosméticos.

\section{INTRODUCTION}

Vitamins are used topically to treat skin diseases, especially in preventive action to delay or prevent certain

*Correspondence: M. M. de Almeida. Pharmacy Department, Faculty of Pharmaceutical Sciences, University of São Paulo. Av. Professor Lineu Prestes, 580 - 05508-900 - São Paulo - SP, Brasil. E-mail: marimandelli@usp.br degenerative changes associated with the aging process, such as dry and flaky skin, and the formation of wrinkles (Maia, 2006).

Studies conducted by Idson, 1994, proved that certain vitamins and their derivatives improve the performance of cosmetics and toiletries. In addition, laboratory tests and clinical trials have provided strong evidence that these 
vitamins, in adequate concentrations, play an important role in protective processes and in repair and renewal of hair, skin and nails (Idson, 1994).

Vitamins $\mathrm{E}$ and $\mathrm{C}$ are natural antioxidants found in many fresh fruits, vegetable oils and wheat germ. Cosmetic products containing these vitamins, such as creams and lotions, have been developed and are commercially available, emphasizing the "natural" aspect of these preparations based on their use of vitamins. Tocopheryl acetate (vitamin E) and ascorbyl tetraisopalmitate (VC-IP) are derivatives from fat soluble vitamins $\mathrm{E}$ and $\mathrm{C}$, respectively. Chemically, they are stable esters of these vitamins and widely used in cosmetic formulations. The chemical structures of these compounds are presented in Figures 1 and 2. Thermal analysis is a set of techniques that allows the measurement of changes in physical or chemical properties (and/or its products of reaction) as a function of temperature and/or time, while the substance is subjected to a controlled temperature program. Thermogravimetry/ derivative thermogravimetry (TG/DTG) and differential scanning calorimetry (DSC) techniques are the most widely distributed and used (Silva et al., 2007).

Thermogravimetry is a thermoanalytical technique in which the variation of mass, due to loss or gain of mass (m) of the sample (solid or liquid), is determined based on temperature $(\mathrm{T})$ and/or time $(\mathrm{t})$, while the sample is submitted to a controlled variation in temperature. Derivative thermogravimetry (DTG) is a mathematical feature representing the first derivative of the thermogravimetric curve. In DTG curves the mass variation is registered in terms of time or temperature, $d m / d t$ and $d m / d T$, respectively. In this case, a series of peaks are obtained in accordance with the stages of loss or gain of mass. The horizontal level in the TG curve corresponds to the similar level in the DTG curve, since $d m / d t=0$. The maximum point on the DTG curve (peak temperature) is obtained when the TG curve shows inflection at a stage in which the change in mass occurs more rapidly (Araújo et al., 2006).

Differential scanning calorimetry (DSC) is a technique which measures the difference in energy supplied to the substance analyzed and a thermally inert reference material according to temperature $(\mathrm{T})$, while the substance investigated and the reference are submitted to a controlled temperature program. (Matos and Machado, 2004). Using the DSC curve, it is possible to measure the difference in energy supplied to the substance and a reference material in function of temperature, both in terms of cooling and heating. Consequently, the temperature and energy related to these events, including melting point, specific heat, glass transition, crystallization, sublimation, decomposition and liquid crystal transitions, can be evaluated by these techniques (Araújo et al., 2006).

In consequence of the growth of the cosmetic industry all over the world, the assessment of raw materials, cosmetic formulations, development and quality control of these formulations have become a priority in this field (ABIHPEC, 2006). The thermoanalytical methods are useful at the pre-formulation stage to obtain information on the physicochemical properties and thermal behavior of the active substances because they are related to its decomposition. Furthermore, data acquired at this stage are extremely important in critical decisions relating to subsequent phases of development (Velasquez Armijo et al., 2004).

The present work aimed to characterize the two raw materials, tocopheryl acetate and ascorbyl tetraisopalmitate, using the techniques of differential scanning calorimetry (DSC) and thermogravimetry/derivative thermogravimetry (TG/DTG) to evaluate the thermal behavior of these active compounds in isolation and when incorporated into cosmetic emulsions.

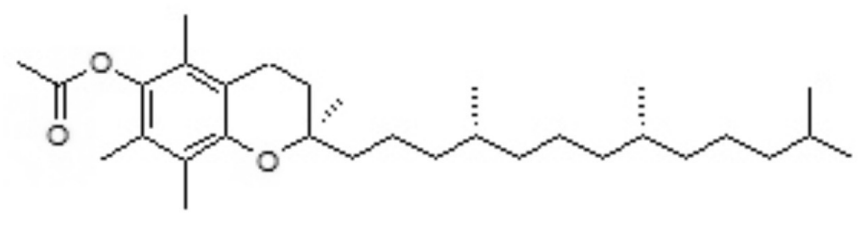

FIGURE 1 - Chemical structure of tocopheryl acetate.

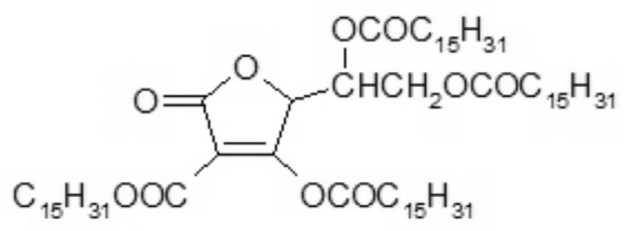

FIGURE 2 - Chemical structure of ascorbyl tetraisopalmitate.

\section{MATERIAL AND METHODS}

\section{Reference standards}

Tocopheryl acetate (96\%) and ascorbyl tetraisopalmitate $(95 \%)$ were donated by a pharmaceutical company and used as a reference standard without previous purification.

\section{Equipment}

Thermogravimetric analyzer, Model TGA-51 and a DSC cell, model 50, both from Shimadzu. 
TABLE I - Base formulation (emulsion) composition

\begin{tabular}{|c|c|c|c|c|}
\hline Phase & Substance (INCI name*) & Origin & $\% \mathrm{p} / \mathrm{v}$ & Function \\
\hline \multirow[t]{4}{*}{ Oily } & Cyclopentasiloxane & Dow Corning $^{\circledR}$ & 2.0 & emollient \\
\hline & Cetostearyl isonanoate & Sederma $^{\circledR}$ & 3.0 & emollient \\
\hline & Caprylic/Capric Triglyceride & Polytechno ${ }^{\circledR}$ & 4.0 & emollient \\
\hline & $\begin{array}{l}\text { Mineral Oil (and) Isopropyl } \\
\text { Palmitate (and) Trilaureth-4 } \\
\text { Phosphate (and) Rapeseed Oil } \\
\text { Sorbitol ester (and) Ammonium } \\
\text { Acryloyldimethyltaureate/VP } \\
\text { Copolymer } \\
\end{array}$ & Clariant $^{\circledR}$ & 5.0 & $\begin{array}{l}\text { polymer donor of } \\
\text { viscosity }\end{array}$ \\
\hline \multirow[t]{6}{*}{ Aqueous } & Metylparaben & Polytechno ${ }^{\circledR}$ & 0.1 & preservative \\
\hline & Propilparaben & Polytechno $^{\circledR}$ & 0.05 & preservative \\
\hline & Phenoxyetanol & Polytechno ${ }^{\circledR}$ & 0.5 & preservative \\
\hline & Disodium EDTA & Polytechno ${ }^{\circledR}$ & 0.1 & chelant \\
\hline & Glycerin & Polytechno ${ }^{\circledR}$ & 4.0 & humectant \\
\hline & Distilled water & & q.s.p. 80.0 & vehicle \\
\hline
\end{tabular}

* International Nomenclature of Cosmetic Ingredients

\section{Sample}

The composition of the emulsion used in the research is presented in Table 1 .

\section{Preparation of cream base (emulsion)}

The method developed to prepare the cream base was innovative. In the conventional method the oil portion is heated and the aqueous phase is added to it at a temperature of $70^{\circ} \mathrm{C}$.

In this research, it was proposed that the aqueous phase be added to the oil phase with the aid of slow agitation. The vitamins were added after being measured or weighed in the proportion of $3 \% \mathrm{w} / \mathrm{v}$ each.

\section{Thermal analysis}

The profiles of TG/DTG curves for the samples: cream base, cream base + Vitamin E (3\%), cream base + VC-IP (3\%), cream base + Vitamin E (3\%) + VC-IP (3\%), Vitamin E (reference substance) and VC-IP (reference substance) were obtained in duplicate using a, Shimadzu model TGA-51 thermobalance under the following conditions: sample mass of about $5 \mathrm{mg}$, measured in an open platinum crucible at the heating rate $(\beta)$ of $10{ }^{\circ} \mathrm{C} \mathrm{min}{ }^{-1}$, in the temperature range spanning from ambient to $600{ }^{\circ} \mathrm{C}$, in a dynamic atmosphere of air $\left(20 \mathrm{~mL} \mathrm{~min}^{-1}\right)$ and $\mathrm{N}_{2}$ $\left(50 \mathrm{~mL} \mathrm{~min}^{-1}\right)$. Differential scanning calorimetry determinations were performed with the same samples in duplica- te, in a cell model DSC 50, Shimadzu. DSC curves were obtained under the following conditions: sample mass of about $2 \mathrm{mg}$, measured in an aluminum crucible at a heating rate of $(\beta) 10^{\circ} \mathrm{C} \mathrm{min}^{-1}$, in a temperature range spanning from ambient to $600^{\circ} \mathrm{C}$ under a dynamic atmosphere of $\mathrm{N}_{2}$ $\left(50 \mathrm{~mL} \mathrm{~min}^{-1}\right)$. For the blank, TG/DTG and DSC curves were constructed under the same experimental conditions.

\section{RESULTS AND DISCUSSION}

For better characterization of materials, it is important to combine data from TG/DTG and DSC tests, as the DSC detects events associated or otherwise to mass loss, while the TG/DTG indicates thermal events related to mass variation (Wendlant, 1986). Thermal analysis can be applied to a wide range of materials such as polymers, synthetic and natural substances, foods, pharmaceuticals and cosmetics in general (Oliveira, Paola Matos, 2004).

According to Silva, Paola Matos (2007), several authors have contributed to the field by applying thermal analysis in studies on materials used in cosmetic preparations, and report the application of several thermoanalytical techniques in the development, production and quality control of cosmetic products.

Silva et al.. (1994) proposed the application of thermal analysis in evaluation of the stability of $\mathrm{O} / \mathrm{W}$. In the study, the technique was suggested for the development of controlled release formulations, investigation of phase transition and stability of formulations.

Thermal analysis was also used by Fujimori, Matos 
and Kedor-Hackmann (1993) for quantitative determination of interlamellar fixed water and dispersed water in cream O/A.

Another thermal analysis study conducted by Pérez et al. (2004) to evaluate the thermal behavior of sunscreens in isolation and in formulations using DSC and TG, showed that the thermal decomposition of sunscreens aroused interest for further studies using isothermal TG to determine the half-life of these materials. The technique has provided important insights into the thermal behavior of sunscreens.

Kovács and colleagues used the DSC for structural analysis of emulsion W/O/A in the development of formulations involving different components, preparation methods and agitation speed. These authors found that the multiple emulsions prepared with non-polar lipophilic agents contained less multiple droplets than those containing polar agents at the same surfactant concentration (Kovács et al., 2005).

Analyzing the DSC curves of tocopheryl acetate (Figure 3) confirmed the presence of three endothermic events characteristic of the thermal behavior of this material. The first event, observed around $50{ }^{\circ} \mathrm{C}$, coincided with the first of the cream base. However, the presence of two other thermal events was detected at temperatures approaching $300{ }^{\circ} \mathrm{C}$ and $400{ }^{\circ} \mathrm{C}$. The vitamin $\mathrm{E}$ in cream base showed a variation of $\Delta \mathrm{H}$ dehydration of $-1.45 \mathrm{~kJ} / \mathrm{g}$ to $1.34 \mathrm{~kJ} / \mathrm{g}$, influencing the thermal behavior of the cream base and indicating its stability in cream.

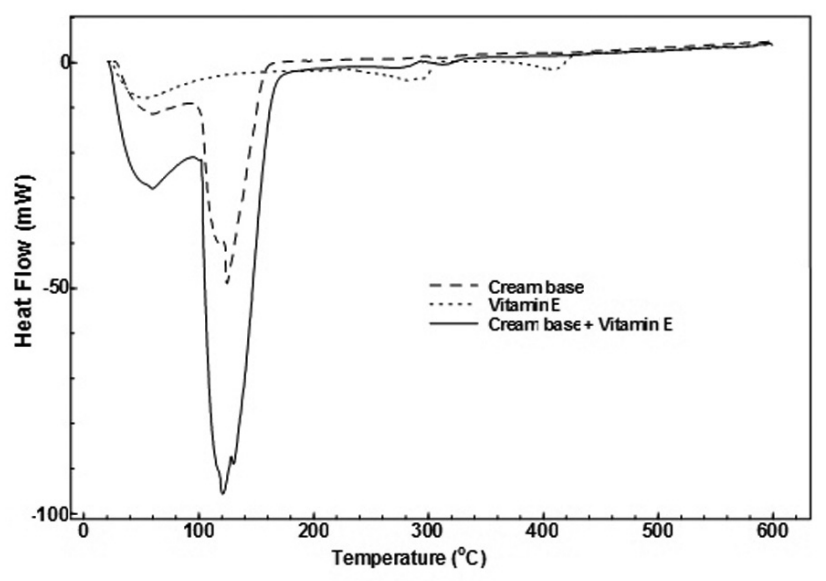

FIGURE 3 - DSC Curves of cream base, vitamin E and cream base with vitamin $\mathrm{E}$ samples obtained in $\mathrm{N} 2$ dynamic atmosphere $\left(50 \mathrm{~mL} \mathrm{~min}{ }^{-1}\right)$ and heating rate of $10^{\circ} \mathrm{C} \mathrm{min}^{-1}$.

Figure 4 shows the thermal behavior of VC-IP in the cream base. Two endothermic events and a peak near $320^{\circ} \mathrm{C}$, characteristic of VC-IP, were observed. Figures 4 and 5 show a change in enthalpy variation between the endothermic events of the cream base and of the endothermic events of the cream base containing vitamins. The presence of vitamins in the formulation is also evident in the same Figures.

A similar study conducted to evaluate the thermal behavior of ascorbic acid and DMAE by DSC, TG/DTG, in isolation and incorporated into emulsions or gels, carried out by Guillen, Batista and Matos (2006), concluded that ascorbic acid in isolation was the substance that showed the greatest stability. According to the authors, the prediction of thermal stability of the components is helpful in controlling the parameters of industrial processes.

Thermogravimetric studies (TG/DTG) of a cream

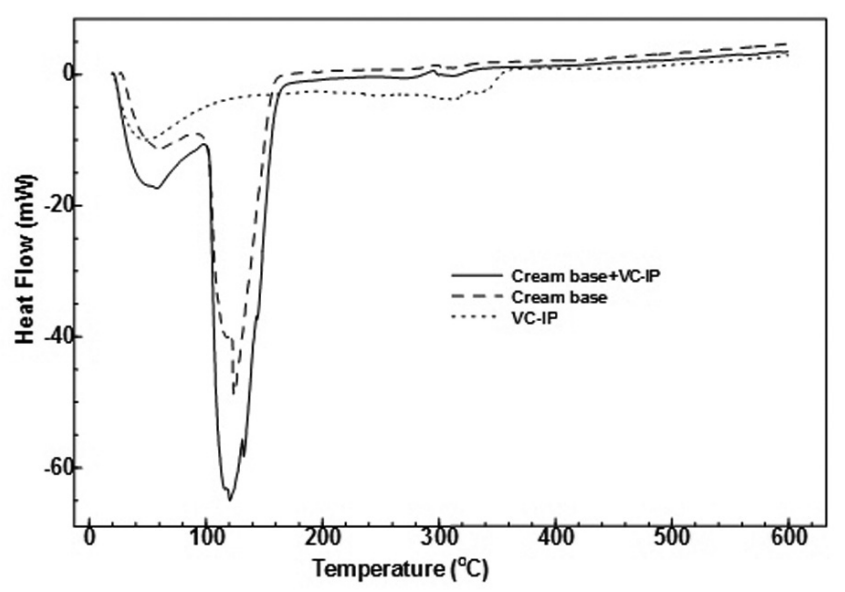

FIGURE 4 - DSC Curves of cream base, VC-IP and cream base with VC-IP samples obtained in a dynamic N2 atmosphere

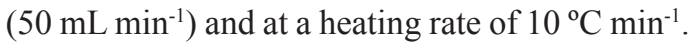

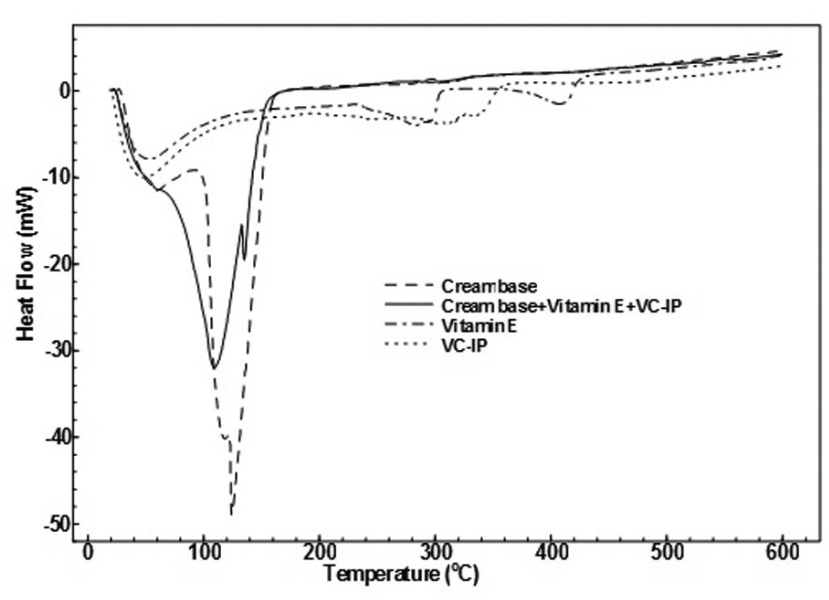

FIGURE 5 - DSC Curves of cream base, VC-IP, vitamin E and cream base with VC-IP and vitamin E samples obtained in a dynamic $\mathrm{N} 2$ atmosphere $\left(50 \mathrm{~mL} \mathrm{~min}^{-1}\right)$ and at a heating rate of $10{ }^{\circ} \mathrm{C} \mathrm{min}^{-1}$. 
formulation based on Ginkgo biloba, Centella asiatica and Fucus vesiculosus by Mothé et al. (2006), proved that these techniques are important tools in the study of thermal stability and decomposition of the product.

The TG/DTG curves obtained in the present study (Figure 6) showed that the cream base presents mass loss from the beginning of the analysis and that it decomposes in the consecutive stages. Tocopheryl acetate is stable up to $\sim 250^{\circ} \mathrm{C}$ showing a thermal decomposition in a single step and subsequent total decomposition. The cream associated with $3 \%$ of tocopheryl acetate presented thermal decomposition in the three consecutive stages.

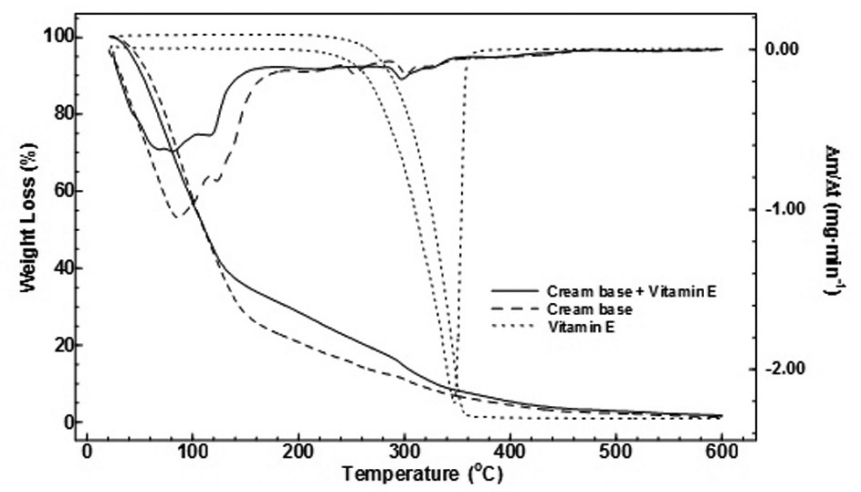

FIGURE 6 - TG/DTG curves of cream base, vitamin E and cream base with vitamin E samples obtained in a mixture of air $\left(20 \mathrm{~mL} \mathrm{~min}^{-1}\right)$ and $\mathrm{N} 2\left(50 \mathrm{~mL} \mathrm{~min}^{-1}\right)$ under a dynamic atmosphere and at a heating rate of $10^{\circ} \mathrm{C} \mathrm{min}$.

Figure 7 shows that the VC-IP is also stable up to $\sim 250^{\circ} \mathrm{C}$ and that it thermally decomposes in two consecutive and concomitant events. The cream showed two steps of thermal decomposition. It started to decompose since

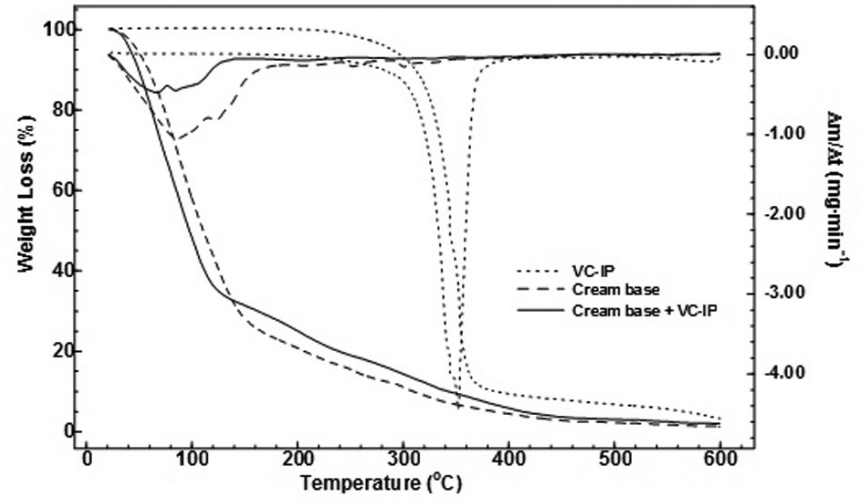

FIGURE 7 - TG/DTG curves of cream base, VC-IP and cream base with VC-IP samples obtained in a mixture of air $\left(20 \mathrm{~mL} \mathrm{~min}^{-1}\right)$ and $\mathrm{N} 2\left(50 \mathrm{~mL} \mathrm{~min}^{-1}\right)$ under a dynamic atmosphere and at a heating rate of $10^{\circ} \mathrm{C} \mathrm{min}^{-1}$. the beginning of the analysis, breaking down completely until the end of the determination.

Figure 8 shows that the thermal decomposition of the sample occurred between 250 and $400^{\circ} \mathrm{C}$ with a sharp loss of mass. Comparison between the TG/DTG curves of the cream base sample and the cream base sample containing vitamins reveals a mass loss at temperatures between 240 and $390{ }^{\circ} \mathrm{C}$ for the cream base with vitamins of $19.6 \%$, while loss for the cream base was $11.7 \%$. This difference suggests that it is possible to evaluate the amount of vitamins in cosmetic formulations, thus enabling the monitoring of the process of vitamin decomposition and cosmetic preparations.

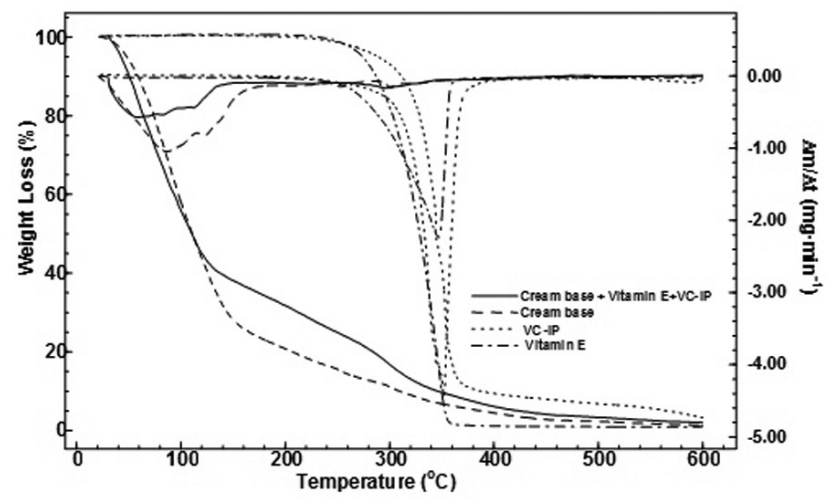

FIGURE 8 - TG/DTG curves of cream base, VC-IP, vitamin E and cream base with VC-IP and vitamin E samples obtained in a mixture of air $\left(20 \mathrm{~mL} \mathrm{~min}^{-1}\right)$ and $\mathrm{N} 2\left(50 \mathrm{~mL} \mathrm{~min}^{-1}\right)$ under a dynamic atmosphere and at a heating rate of $10^{\circ} \mathrm{C} \mathrm{min}^{-1}$.

Silva, Paola and Matos (2007) concluded that these analytical techniques are of great importance in cosmetics due to their wide variety of applications. They can therefore be employed in quality control of raw materials and finished products, presenting important potential in the development and characterization of new products.

\section{CONCLUSION}

In this preliminary stability study the vitamins were found to be stable up to a temperature of approximately $250^{\circ} \mathrm{C}$. Furthermore, due to the alteration in the enthalpy variation between the endothermic events of the cream base and the endothermic events of vitamins, the techniques allow the identification of these substances in cosmetic formulations. The TG/DTG and DSC curves were important tools to characterize the thermal profile of these vitamins and creams, and can be used for routine analysis at quality control laboratories in cosmetic industries. 


\section{ACKNOWLEDGMENTS}

The authors would like to thank FAPESP and the doctoral students Ingrid Graça and Ednaldo Conceição Souza from LABCAT - Laboratory of Catalysis of the University Federal of Bahia for their assistance.

\section{REFERENCES}

ABIHPEC - Associação Brasileira das Indústrias de Higiene Pessoal, Cosméticos e Perfumaria. Anuário anual, 2006. Available at: http://www.abihpec.org.br/conteudo/material/ apresentacaosetor_2006_2007.pdf. Accessed on: fev. 27 2008.

ARAÚJO, A. A. S.; MERCURI, L. P.; SEIXAS, S. R. S.; STORPIRTIS, S.; MATOS, J. R. Determinação dos teores de umidade e cinzas de amostras comerciais de guaraná utilizando métodos convencionais e análise térmica. Rev. Bras. Cienc. Farm., São Paulo, v.42, n.2, p.269-277, 2006.

FUJIMORI, Y.; MATOS, J. R.; KEDOR-HACKMANN, E. R. M. Utilização de análise térmica na determinação quantitativa de água fixa interlamelar e água dispersa em creme o/a. In: SEMINÁRIO DE PÓS-GRADUAÇÃO DA FACULDADE DE CIÊNCIAS FARMACÊUTICAS DA USP, 8, São Paulo, 1993. Resumos. São Paulo: Coordenadoria de Comunicação Social/USP, 1993. p.90.

GUILLEN, J. S. Q.; BATISTA, I. A. S. A.; MATOS, J. R. Contribuição da análise térmica na avaliação de princípios ativos empregados na prevenção do envelhecimento da pele isolados e/ou incorporados em géis e emulsões. Cosmet. Toiletries, Carol Stream, v.18, n.2, p.50-52, 2006.

IDSON, B. Vitaminas e a pele. Cosmet. Toiletries, São Paulo, v.6, n.3, p.59-68, 1994.

KOVÁCS, A.; CSÓKA, I.; KÓNYA, M.; CSÁNYI, E.; FEHÉR, A.; ERÒS, I. Structural analysis of w/o/w multiple emulsions by means of DSC. Eur. J. Pharm. Sci., Amsterdam, v.25, suppl.1, p.S135-S137, 2005.

MAIA CAMPOS, P. M. B. G. Vitaminas em cosméticos. Cosmet. Toiletries, São Paulo, v.18, n.6, p.52-62, 2006.

MATOS, J. R; MACHADO, L. D. B. Introdução à análise térmica e termogravimetria. (1.ed.). São Paulo: Artliber, p.209-228, 2004.
MOTHÉ, C. G.; CARESTIATO, T.; BUSNARDO, N. G.; GARRIDO, J. Estudo termoanalítico do creme anticelulite à base de Gingko biloba, Centella asiática e Fucus vesiculosus. In: CONGRESSO BRASILEIRO DE ANÁLISE TÉRMICA E CALORIMETRIA, 5., Poços de Caldas, 2006. Livro de resumos. Poços de Caldas: ABRATEC, 2006. p.351.

OLIVEIRA, F. F.; PAOLA, M. V. R. V.; MATOS, J. R. Análise térmica aplicada aos produtos cosméticos. Cosmet. Toiletries, Carol Stream, v.16, n.3, p.52-54, 2004.

PÉREZ- GONZÁLES, M. L. L.; KEDOR-HACKMANN, E. R. M.; IGNÁCIO, R.F.; SAITO, C.; MATOS, J. R. Estudo termoanalítico de filtro solares. In: CONGRESSO BRASILEIRO DE ANÁLISE TÉRMICA E CALORIMETRIA, 4., Congresso Pan Americano de Análise Térmica e Calorimétrica, 2., Alfenas, 2004. Livro de resumos. Alfenas: ABRATEC, 2004. p.35.

SILVA, M. A. S; KELMANN, R. G; FOPPA, T.; CRUZ, A. P.; BERTOL, C. D.; SARTORI, T.; GRANADA, A.; CARMIGNAN, F.; MURAKAMI, F. S. Thermal analytical study of fluoxetine hydrochloride. J. Therm. Anal. Calorim., v.87, n.2, p.463-467, 2007.

SILVA, M. A. S.; NACCO, R.; MATOS, J. R. Determinação da estabilidade de emulsões pelo uso de análise térmica. In: SEMINÁRIO DE PÓS-GRADUAÇÃO DAFACULDADE DE CIÊNCIAS FARMACÊUTICAS DA USP, 9, São Paulo, 1994. Resumos. São Paulo: FCF/USP, 1994. p.46.

SILVA, E. C.; PAOLA, M. V. R.; MATOS, J. R. Análise térmica aplicada à cosmetologia. Rev. Bras. Cien. Farm., São Paulo, v.43, n.3, p.347-356, 2007.

VELASQUEZ-ARMIJO, C. J.; COSTA, I. M.; LONGHINI, R.; PETZHOLD, C. L.; PETROVICK, P. R. Métodos termoanalíticos e suas aplicações nas ciências farmacêuticas. $\mathrm{Cad}$. Farm., Porto Alegre, v.20, n.1. p.29-47, 2004.

WENDLANT, W. W. Thermal analysis. (3.ed.). New York: John Wiley \& Sons, 1986. p.1. (Chemical analysis, v.19).

Received for publication on $13^{\text {th }}$ November 2008 Accepted for publication on $29^{\text {th }}$ July 2009 